\title{
HAEMATOLOGICAL PROFILE IN PAEDIATRIC AGE GROUP (0 - 12 YEARS) WITH TYPE 1 DIABETES MELLITUS WITH A SPECIAL REFERENCE TO ANAEMIA - A PILOT STUDY
}

Mamina Bhoi ${ }^{1}$, B. Krishnaswamy², P. Viswanathan ${ }^{3}$, L. Lakshmana Rao ${ }^{4}$

HOW TO CITE THIS ARTICLE:

Mamina Bhoi, B Krishnaswamy, P Viswanathan, L Lakshmana Rao. "Haematological profile in paediatric age group (0 - 12 years) with type 1 Diabetes mellitus with a special reference to anaemia - A pilot study". Journal of Evolution of Medical and Dental Sciences 2013; Vol2, Issue 33, August 19; Page: 6179-6195.

ABSTRACT: It has been demonstrated that industrialization and modernization lead to sedentary lifestyle, obesity and higher risk of metabolic disorders, of which Diabetes and Anemia are common problems encountered in clinical medicine. In the present study the prevalence of anemia and its sex predilection among pediatric age group from 0 - 12 years with Type 1 diabetes mellitus hailing from rural areas, in and around Chidambaram, District - Cuddalore, Tamilnadu, India. A total of randomly selected 50 Type 1 Diabetes Mellitus children aging 0-12 years, attending the diabetic clinic of Rajah Muthiah Medical College and Hospital, during the period of January 2012 to May 2012 were included in the study. $66 \%$ of the subjects were anemic with female preponderance. Microcytic hypochromic anemia was the most common type observed.

KEY WORDS: Anemia, Type 1 Diabetes Mellitus, Pediatric age group (0 to 12 years).

INTRODUCTION: Anemia is functionally defined as a "decrease in the competence of blood to carry oxygen to tissues, thereby causing tissue hypoxia" 1 . As many as $80 \%$ of children in developing countries and $20 \%$ in US will be anemic at some point by 18 years of age ${ }^{2}$.Anemia is widely prevalent in India and affects both sexes and all ages ${ }^{3}$. In infancy and childhood, anemia is associated with behavioral and cognitive delays, including impaired learning, decreased school achievement, and low score on tests of mental and motor development. An estimated 30 percent of world's population is anemic, with the global prevalence of anemia among 0-12 years old children to be 36 percent 6,7 and 77 percent in developing regions respectively ${ }^{8,9}$

Statistical projection about India suggests that the number of diabetics will rise from 15 million in 1995 to 57 million in 2025 making it the country with the highest number of diabetic patients in the world (King et al., 1998). Asian Indians have a racial predisposition to develop diabetes (Zimmet, 1999). Anemia may occur with diabetes because the hormone that regulates red blood cell production, erythropoietin (EPO), is produced by the kidneys. Kidney damage at several levels is a complication of diabetes, and one problem often leads to the other. A simple blood test, the complete blood count or $\mathrm{CBC}$, is used to check for anemia. The two elements of the test that reveal anemia are hemoglobin and hematocrit. Hemoglobin is the part of red blood cells that carries oxygen to the cells. Hematocrit indicates the percentage of red blood cells in the blood.33\% of type 1 diabetics develop chronic kidney disease after fifteen years ${ }^{10}$

AIMS AND OBJECTIVES: The present study is undertaken to evaluate:

1. The prevalence of anemia among pediatric age group of 0 to 12 years with type 1 diabetes mellitus.

2. Sex predilection among the study group. 


\section{MATERIALS AND METHODS:}

\section{Instruments used are:-}

- AUTOMATED CELl COUNTER (MODEL \& COMPANY: MYTHIC 18, ORPHEE SA, C2 DIAGNOSTICS, FRANCE).

- AUTOMATED CLINICAL CHEMISTRY-COLORIMETRIC-IMOLA, Rx Series, RANDOX, UK.)

- IMMULITE 1006 Systems, DIAGNOSTIC PRODUCT CORPORATION, USA)

Fifty Type 1 diabetic children aged from 0 to 12 years attending the diabetic clinic of Rajah Muthiah Medical College and Hospital, between January 2012 and June 2012. The children were divided into 6 groups

$\begin{array}{lll}\text { Group I } & : & 0-2 \text { years } \\ \text { Group II } & : & 2-4 \text { years } \\ \text { Group III } & : & 4-6 \text { years } \\ \text { Group IV } & : & 6-8 \text { years } \\ \text { Group V } & : & 8-10 \text { years } \\ \text { Group VI } & : & 10-12 \text { years }\end{array}$

- Blood samples were collected by venipuncture into containers with di-potassium EDTA. All samples were analyzed for hematological parameters using automated cell counter. Iron profile studies were conducted on 18 randomly selected blood samples.

- Informed written consent from the parents was taken.

Inclusion Criteria: 0-12 years paediatric patients with Type 1 diabetes mellitus.

Exclusion Criteria: Children with:-

- Acute infections

- Communicable diseases like Tuberculosis, Hepatitis

- On iron supplements

- History of recent blood transfusion

- Known cases of hemoglobinopathies

Anemia Criteria for Diagnosis: Anemia was defined using WHO criteria for different age groups. With these criteria, the hemoglobin cut off used to define anemia in children between age groups 0 to 12 years is $<12 \mathrm{gm} / \mathrm{dl}$. Anemia was further graded as mild $(\mathrm{Hb} 9.0-11.9 \mathrm{~g} / \mathrm{dl})$, moderate $(\mathrm{Hb}=$ $6.0-8.9 \mathrm{~g} / \mathrm{dl})$ and severe $(\mathrm{Hb}<6.0 \mathrm{~g} / \mathrm{dl})$ based on hemoglobin values. Anaemia can be initially classified morphologically according to the erythrocyte indices like Mean Corpuscular Volume (MCV). The general categories of the morphological classification includes: 1. Macrocytic Normochromic; 2. Normocytic Normochromic and 3. Microcytic Hypochromic.

Sample Collection for Hematological Parameters and Iron Profile Studies: Under aseptic precautions blood collected from antecubital vein and immediately transferred into two sterile glass bottles, one with di-potassium EDTA as anticoagulant and was analyzed in the automated cell counter and the other without EDTA for Iron Profile Studies. 
RESULTS: Hematological parameters in 50 pediatric patients with Type 1 diabetes mellitus between 0-12 years were evaluated in the present study. The school children were categorized into six groups. [Table 1/Chart 1]

- Sex Distribution: Among the study group, 26(52\%) were found to be girls and 24(48\%) were found to be boys. Overall male to female ratio in the present study was found to be 1:1.1.Group III, Group IV and Group VI showed male predominance while female predominance was seen in Group I, Group V. [Table 2/Chart 2]

- RBC Count:28\% of patients showed RBC count less than normal limit, while majority of school going children aged between $0-12$ years had RBC counts within normal range,.[Table 3/Chart 3]

- Hematocrit (HCT):48\% of patients had hematocrit less than $33.0 \%$ and $52 \%$ of patients had hematocrit more than 33.0\%. [Table 4/Chart 4]

- Hemoglobin: $66 \%$ of patients had hemoglobin $<12.0 \mathrm{~g} / \mathrm{dl}$, among which, mild degree of anemia was most common followed by moderate degree. $34 \%$ of patients had hemoglobin greater than or equal to $12.0 \mathrm{~g} / \mathrm{dl}$.[Table 5/Chart 5]

- Mean Corpuscular Volume (MCV): 52\% had MCV below 80fl (n=26); 40\% had MCV within the normal range, $(n=20)$ and 8\% had MCV more than $100 \mathrm{fl} .(\mathrm{n}=4)$ [Table 6/Chart 6]

- Mean Corpuscular Hemoglobin (MCH):44\% of patients had MCH below 25.9 pg, (n=22); $38 \%$ had MCH within normal range (26.0 - 34.9pg); $(\mathrm{n}=19)$ and 18\% had MCH more than $35.0 \mathrm{pg}$, (n=9). [Table 7/Chart 7]

- Mean Corpuscular Hemoglobin Concentration (MCHC):40\% had MCHC below $30.9 \mathrm{~g} / \mathrm{dl}$, $(\mathrm{n}=20) .36 \%$ had MCHC within normal range $(31.0-36 \mathrm{~g} / \mathrm{dl}),(\mathrm{n}=18)$ and $24 \%$ had MCH more than $35.0 \mathrm{~g} / \mathrm{dl},(\mathrm{n}=12)$.[Table 8/Chart 8]

- Red Cell Distribution width (RDW):48\% had RDW within the range (10.0 - 16.0\%), (n=24). 52\% had RDW >16.0\%, $(n=26)$.[Table 9/Chart 9]

- Morphologic Classification of Anaemia: In the present study, according to the above classifications following three types of anemia are seen: 29 school going children had Microcytic Hypochromic type, due to iron deficiency anemia, 13 children had Normocytic Normochromic type of anemia \& 8 children had Macrocytic Normochromic type of anemia. [Table 16].

COMPARISION OF HEMATOLOGICAL AND BIOCHEMICAL PARAMETERS: Out of 50 randomly selected paediatric age Type 1 Diabetic children aged between 0-12 years, iron profile studies were carried out in 18 children.

\section{IRON PROFILE STUDY IN 18 PATIENTS}

- Serum Iron: In 18 patients, 12 of them had serum iron $<60 \mu \mathrm{g} / \mathrm{dl}, 6$ had serum iron within normal range $(60-180 \mu \mathrm{g} / \mathrm{dl})$.[Table 10,Chart 10]

** (Equipment: AUTOMATED CLINICAL CHEMISTRY-COLORIMETRIC-IMOLA, Rx Series, RANDOX, UK)

- Total Iron Binding Capacity (TIBC):In 18 patients, 12 of them had increase in TIBC $(>440 \mu \mathrm{g} / \mathrm{dl}), 6$ were within normal range $(240-440 \mu \mathrm{g} / \mathrm{dl})$ [Table 11/Chart 11] 
** (Equipment: AUTOMATED CLINICAL CHEMISTRY-COLORIMETRIC-IMOLA, Rx Series, RANDOX,UK)

- PERCENT SATURATION:- In 18 patients, 12 of them had percent saturation $<30 \%$ and 6 of them $>30 \%$ [Table 12/Chart 12]

** Calculated manually by using the formula: (\% Saturation=Serum Iron x 100/ TIBC)

- Serum Ferritin: In 18 patients, 12 of them had serum ferritin $<20 \mu \mathrm{g} / \mathrm{l}, 6$ of them had serum ferritin in within normal range 20-25 $\mu \mathrm{g} / \mathrm{l}$ [Table 13/Chart 13]

** (Equipment: IMMULITE 1006 systems, DIAGNOSTIC PRODUCT CORPORATION, USA)

DISCUSSION: The present study is undertaken to study the prevalence of anemia and its sex predilection among pediatric age group with Type 1 Diabetes Mellitus. Anaemia in these children was defined and classified using WHO criteria ( $\mathrm{Hg}<12 \mathrm{~g} / \mathrm{dl}$ ) ${ }^{11}$.An estimated 30 percent of world's population is anemia, with the global prevalence of anemia among 0-12 years old children to be 36 percent 7,8 and 77 percent in developing regions respectively ${ }^{9,10}$. In earlier studies prevalence of anemia among 5-14 years old urban and rural Indian children was found to be in the range of 66.7 77 percent $^{8,12}$. Recent studies on prevalence of anemia have been among pre-school children only ${ }^{13}$, 14. The prevalence was as high as 93 percent in children from Varanasi ${ }^{16}$. The recent NFHS-2 survey ${ }^{17}$ estimated prevalence of anemia among children of Delhi to be 69 percent. The higher prevalence of anemia could be due to inclusion of younger children (6-35 months) in the study group ${ }^{16}$. In the present study, prevalence of anemia was $66 \%$ which correlated with the above mentioned studies [Tables 14/Chart 14].

According to the study conducted by Gomber et al (1998) the male female ratio was 1.4:118. There was no difference in sex distribution in the study conducted by Kapur et al14 (2002) and Halileh et al $^{19}$ (2005) and the study conducted by Sunil Gomber et al ${ }^{15}$ (2003), male female ratio was 1:1.2. In the present study, girls are found to be more anemic when compared to boys. The male female ratio is (1:1.1). [Table 15/Chart 15].

Iron deficiency was found to be the commonest cause in the present study and was demonstrated in 29 children out of 50 in the study group (58\%) [Table 16]. Also iron deficiency was demonstrated in $91 \%$ of the 18 children randomly selected for iron profile studies.

CONCLUSION: In the present study among the pediatric age group with Type 1 Diabetes Mellitus $(0$ to 12 years), the prevalence of anemia is $66 \%$ ( as per WHO criteria of anemia). Microcytic hypochromic anemia is found in $58 \%$ of the children in the study group and iron deficiency was demonstrated in $91 \%$ of the 18 children randomly selected for iron profile studies. Female preponderance is noted in the study group pointing to the prevalence of neglect of female child in the community even in this era of $22^{\text {nd }}$ century.

The principal target of nutritional improvement in the community is the family. The mother needs to be educated on the selection of right kind of local food within the level of their purchasing power ${ }^{20}$.

ACKNOWLEDGEMENT: The authors thank the Dean, Medical Superintendent; RMMC\&H. Authors also thank all the lovely pediatric patients of RMMC\&H, for being a part of this study group. 


\section{REFERENCES:}

1. McKenzie SB. The Anemias In: Text book of hematology, $2^{\text {nd }}$ edition USA. Williams and Wilkins 1996; 161-369.

2. Irwin JJ, Kirchner JT; Anaemia in children. AM Family phys 2001; 64(8): 1-12.

3. Latham MC. Human nutrition in the developing world. Rome: FAO, 1997:147-55

4. Mckenzie SB. The Anemias In: Text book of Hematology $2^{\text {nd }}$ Edition UA> Williams and Wilkins 1996; 161-369.

5. Chen AWU, Lesperence L, Bernstein H. Screening of Iron Deficiency Anemia. Paed in Review 2002; 2002; 23(5) 171-177.

6. DeMaeyer EM, Dallman P, Gurney JM, Hallberg L, Sood SK, Srikantia SD. Preventing and controlling iron deficiency anaemia through primary health care. Geneva: World Health Organization; 1989 p. 8-9.

7. DemMeyer E, Adiels-Tegman M. The prevalence of anemia in the world. World Health Stat Q 1985; 38: 302-16.

8. Verma M, Chhatwal J, Kaur G. Prevalence of anemia urban school children of Punjab, Indian Pediatr 1998; 35: 1181-86.

9. Stoltzfus RJ, Chwaya HM, Tielsch JM, Schulze KJ, Albonico M, Savioli L. Epidemiology of iron deficiency anemia in Zanzibari school children: The importance of hookworms. Am J ClinNutr 1997; 65: 153-9.

10. NIDDK, Diabetes Control and Complications Trial Research Group. N Engl J Med. 1993; 329(14):977-86.

11. Clinical Laboratory Hematology. Eds. Mckenzie S B, 2nd Edition, New Jersey, USA, Pearson Education, Inc. 2004, Chapter 10; 162-186.

12. Malhotra AK, Srivastava RN. A study on impact of socioeconomic status on haemoglobin levels of rural school children of district Wardha. Indian J PrevSoc Med 1982; 13: 95-9.

13. Sidhu S, Kumari K, Uppal M. Prevalence of anameia in schedule cast preschool children of Punjab. Indian J Med Sci 2002; 56: 218-21.

14. Kapoor D, Agarwal KN, Sharma S, Kela K, Kaur I. iron Status of children aged 9-36 months in an urban slum integrated Child Development services project in Delhi. Indian pediatr 2002; 39: 136-44.

15. Sunil Gomber, Bhana, Nishi Madan. Prevalence \& etiology of nutritional anemia among school children of urban slums Indian J Med RES 118, October 2003, p 167-171.

16. Agarwal DK, Upadhyay SK, Agarwal KN, Singh RD, Tripathi AM. Anaemia and mental functions in rural primary school children. Ann Trop Paediatr 1989; 9: 194-8.

17. Nutrition and the prevalence of anemia: anemia among children. In: National Family health Survey 9NFHS-2), 1998-99, International Institute for Population Sciences, Mumbai, India; 2000 p. 271-3.

18. Gomber S, Kumar S, Rusia U, Gupta P, Agarwal KN, Sharma S. Prevalence and etiology of nutritional anemias in early childhood in an urban slum. Ind J Med Res 1998; 107: 269-272.

19. Halileh S, Gordon NH. Determination of anemia in pre-school in the occupied Palestinian territory, J tropical Pediatrics, 2005; 52:12-8.

20. Park's textbook of preventive and social medicine, K. Park twenty first edition 2011:575-604. 


\section{ORIGINAL REPORT}

Table - 1: Groups in present study

\begin{tabular}{|c|c|c|c|c|c|c|}
\hline Groups & $\begin{array}{c}\text { Group I } \\
\text { 0 - 2years }\end{array}$ & $\begin{array}{c}\text { Group II } \\
\text { 2 - 4years }\end{array}$ & $\begin{array}{c}\text { Group III } \\
\text { 4 - 6 years }\end{array}$ & $\begin{array}{c}\text { Group IV } \\
\text { 6 - 8years }\end{array}$ & $\begin{array}{c}\text { Group V } \\
\text { 8 - 10years }\end{array}$ & $\begin{array}{c}\text { Group VI } \\
\text { 10 - 12years }\end{array}$ \\
\hline Number of Cases & 4 Cases & 6 Cases & 11 Cases & 5 Cases & 9 Cases & 15 Cases \\
\hline
\end{tabular}

\section{Chart - 1: Age Distribution}

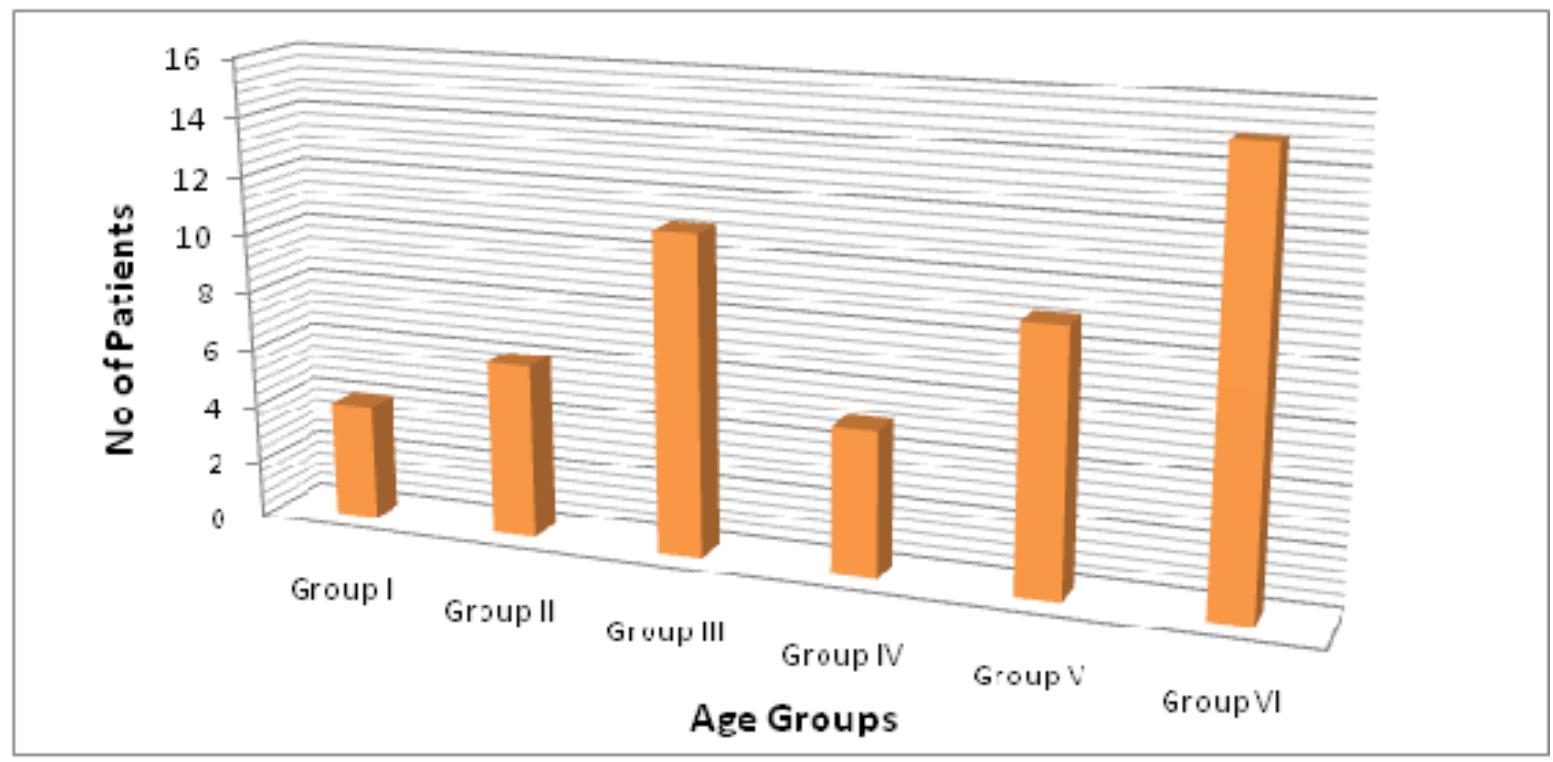

Table - 2: Sex Distribution

\begin{tabular}{|c|c|c|c|c|}
\hline AGE GROUP & GIRLS & PERCENTAGE & BOYS & PERCENTAGE \\
\hline Group I & 1 & 2 & 3 & 6 \\
\hline Group II & 3 & 6 & 3 & 6 \\
\hline Group III & 7 & 14 & 4 & 8 \\
\hline Group IV & 3 & 6 & 2 & 4 \\
\hline Group V & 3 & 6 & 6 & 12 \\
\hline Group VI & 9 & 18 & 6 & 12 \\
\hline Total & 26 & 52 & 24 & 48 \\
\hline
\end{tabular}




\section{ORIGINAL REPORT}

\section{Chart 2: Sex Distribution}

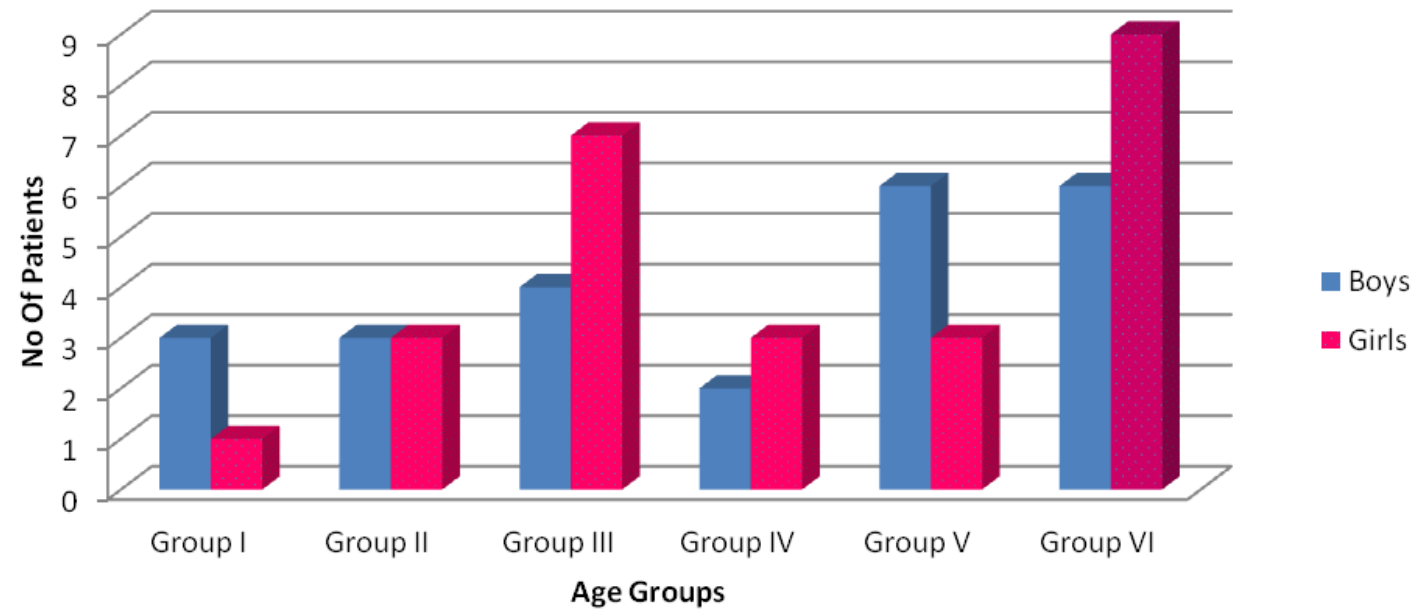

Table - 3: RBC Count in the study groups

\begin{tabular}{|c|c|c|c|c|c|c|c|c|}
\hline \multicolumn{2}{|c|}{ Groups } & Group I & Group II & Group III & Group IV & Group V & Group VI & Total \\
\hline RBC COUNTS & $<\mathbf{3 . 6}$ & $1(25 \%)$ & $2(33.33 \%)$ & $3(27.27 \%)$ & $1(20 \%)$ & $3(33.33 \%)$ & $4(26.66 \%)$ & $14(28 \%)$ \\
\cline { 2 - 10 }$\left(\mathbf{x 1 0}^{12} / \mathbf{L}\right)$ & $\mathbf{3 . 6 - 5 . 5}$ & $3(75 \%)$ & $4(66.66 \%)$ & $8(72.72 \%)$ & $4(80 \%)$ & $6(66.66 \%)$ & $11(73.33 \%)$ & $36(72 \%)$ \\
\hline
\end{tabular}

\section{Chart 3: RBC count}

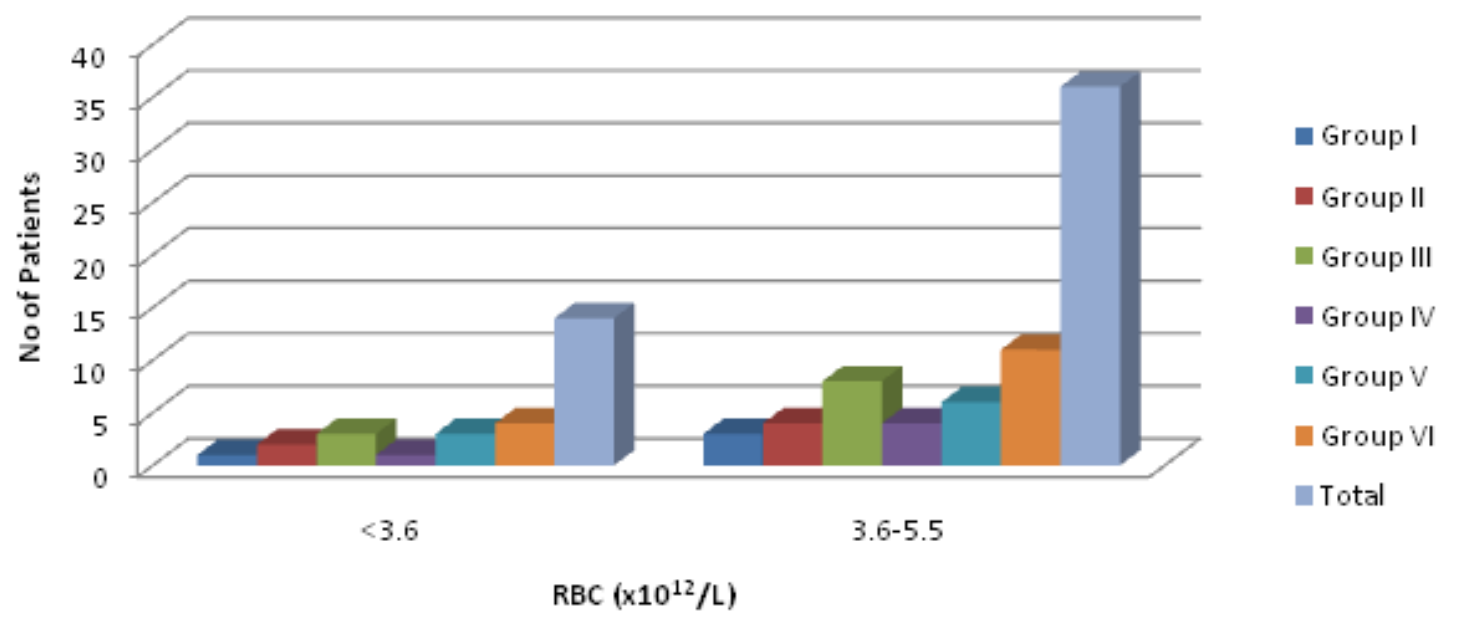

Table - 4: HCT values in the study groups

\begin{tabular}{|c|c|c|c|c|c|c|c|c|}
\hline \multicolumn{2}{|c|}{ Groups } & Group I & Group II & Group III & Group IV & Group V & Group VI & Total \\
\hline \multirow{2}{*}{ HEMATOCRIT } & $<\mathbf{3 3}$ & $2(50 \%)$ & $4(66.66 \%)$ & $7(63.63 \%)$ & $2(40 \%)$ & $3(33.33 \%)$ & $6(40 \%)$ & $24(48 \%)$ \\
\cline { 2 - 9 } & $>\mathbf{3 3}$ & $2(50 \%)$ & $2(33.33 \%)$ & $4(36.36 \%)$ & $3(60 \%)$ & $6(66.66 \%)$ & $9(60 \%)$ & $26(52 \%)$ \\
\hline
\end{tabular}




\section{ORIGINAL REPORT}

\section{Chart 4: Hematocrit Values}

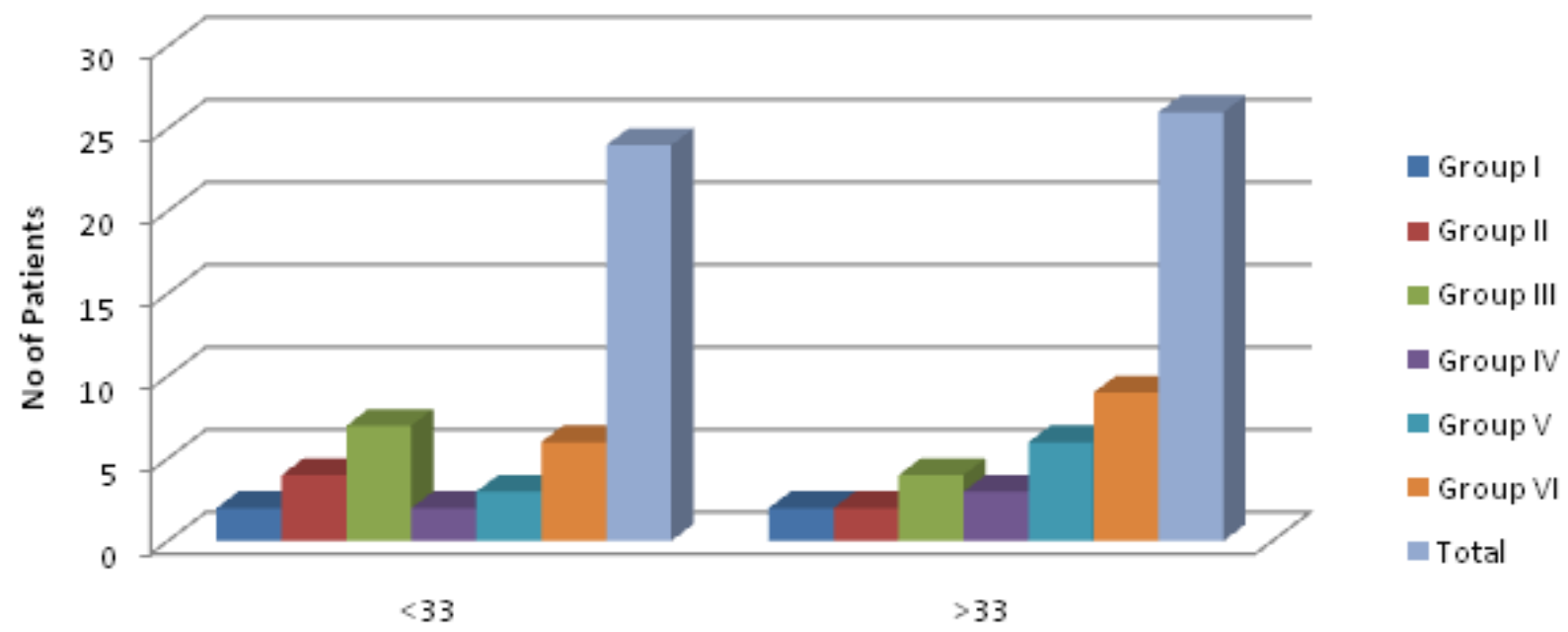

HCT $(\%)$

Table - 5: Hb values in the study groups

\begin{tabular}{|c|c|c|c|c|c|c|c|c|}
\hline \multicolumn{2}{|c|}{ Groups } & Group I & $\begin{array}{c}\text { Group } \\
\text { II }\end{array}$ & $\begin{array}{c}\text { Group } \\
\text { III }\end{array}$ & $\begin{array}{c}\text { Group } \\
\text { IV }\end{array}$ & Group V & $\begin{array}{c}\text { Group } \\
\text { VI }\end{array}$ & Total \\
\hline \multirow{2}{*}{$\begin{array}{c}\text { HEMOGLOBIN } \\
(\mathbf{g} / \text { dI) }\end{array}$} & $\begin{array}{c}\mathbf{9 . 0 - 1 1 . 9} \\
\text { (mild) }\end{array}$ & $1(50 \%)$ & $2(33 \%)$ & $2(18 \%)$ & $4(80 \%)$ & $6(66.66 \%)$ & $10(67 \%)$ & $25(50 \%)$ \\
\cline { 2 - 8 } & $\begin{array}{c}\mathbf{6 . 0 - 8 . 9} \\
\text { (moderate) }\end{array}$ & - & - & - & $1(20 \%)$ & $3(33.33 \%)$ & $3(20 \%)$ & $7(14 \%)$ \\
\cline { 2 - 8 } & $\begin{array}{c}<\mathbf{6 . 0} \\
(S e v e r e)\end{array}$ & - & $1(17 \%)$ & - & - & - & - & $1(2 \%)$ \\
\hline
\end{tabular}

Chart 5: Hemoglobin values

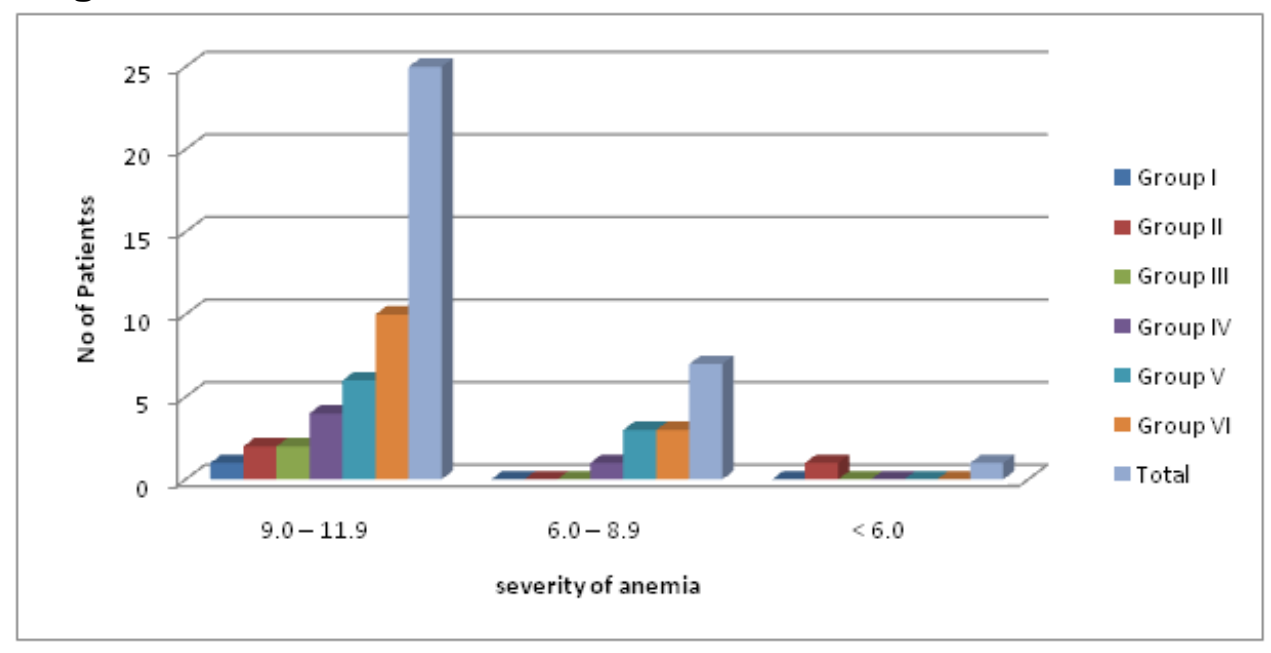


Table - 6: MCV values in the study groups

\begin{tabular}{|c|c|c|c|c|c|c|c|c|}
\hline \multicolumn{2}{|c|}{ Groups } & $\begin{array}{c}\text { Group } \\
\text { I }\end{array}$ & Group II & Group III & $\begin{array}{c}\text { Group } \\
\text { IV }\end{array}$ & Group V & Group VI & Total \\
\hline \multirow{3}{*}{ MCV(fl) } & $<80.00$ & $3(75 \%)$ & $4(66.67 \%)$ & $6(54.54 \%)$ & $3(60 \%)$ & $6(66.67 \%)$ & $4(26.67 \%)$ & $26(52 \%)$ \\
\cline { 2 - 9 } & $80.0-100.0$ & $1(25 \%)$ & $1(16.67 \%)$ & $3(27.28 \%)$ & $2(40 \%)$ & $2(22.22 \%)$ & $11(73.33 \%)$ & $20(40 \%)$ \\
\cline { 2 - 9 } & $>100.0$ & - & $1(16.67 \%)$ & $2(18.18 \%)$ & - & $1(11.11 \%)$ & - & $4(8 \%)$ \\
\hline
\end{tabular}

\section{Chart 6: MCV VALUES}

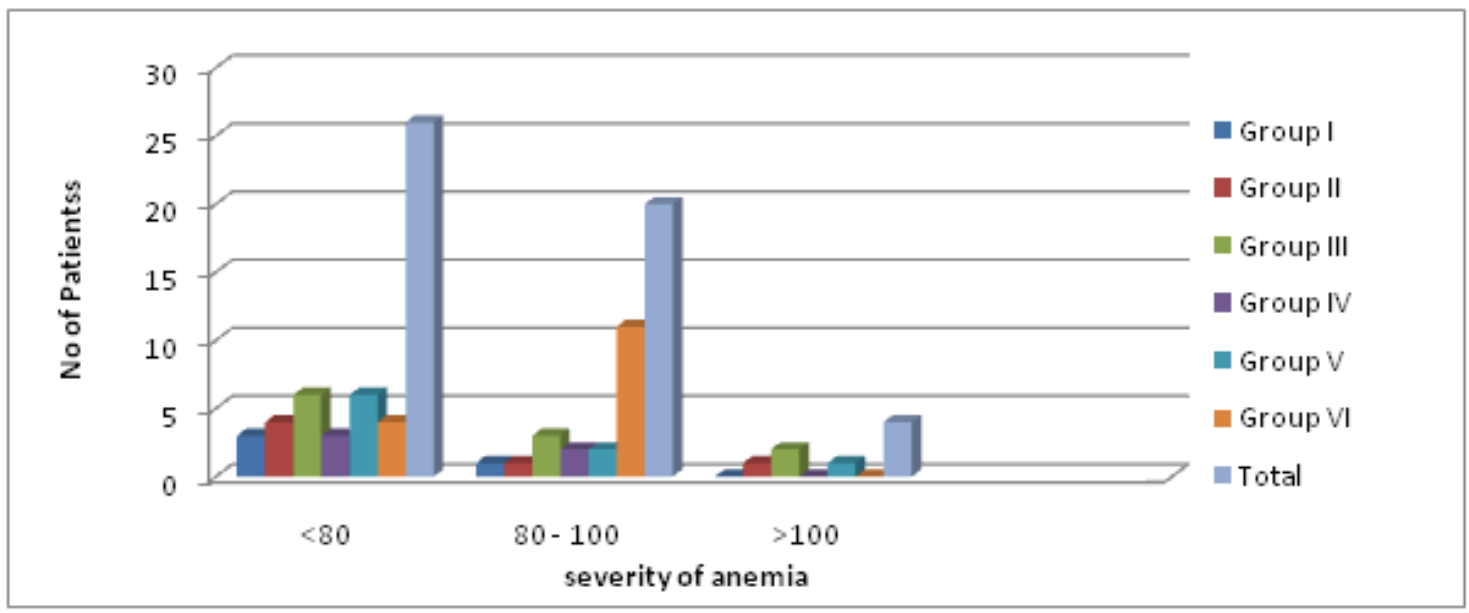

Table - 7: MCH values in the study groups

\begin{tabular}{|c|c|c|c|c|c|c|c|c|}
\hline \multicolumn{2}{|c|}{ Groups } & Group I & Group II & Group III & Group IV & Group V & Group VI & Total \\
\hline \multirow{3}{*}{ MCH(pg) } & $<26$ & $2(50 \%)$ & $3(50 \%)$ & $7(63.64 \%)$ & $2(40 \%)$ & $3(33.33 \%)$ & $5(33.33 \%)$ & $22(44 \%)$ \\
\cline { 2 - 8 } & $26-34$ & $1(25 \%)$ & $2(33.33 \%)$ & $3(27.27 \%)$ & $3(60 \%)$ & $4(44.44 \%)$ & $6(40 \%)$ & $19(38 \%)$ \\
\cline { 2 - 8 } & $>34$ & $1(25 \%)$ & $1(16.67 \%)$ & $1(9.09 \%)$ & - & $2(22.22 \%)$ & $4(26.67 \%)$ & $9(18 \%)$ \\
\hline
\end{tabular}

\section{Chart 7: MCH VALUES}

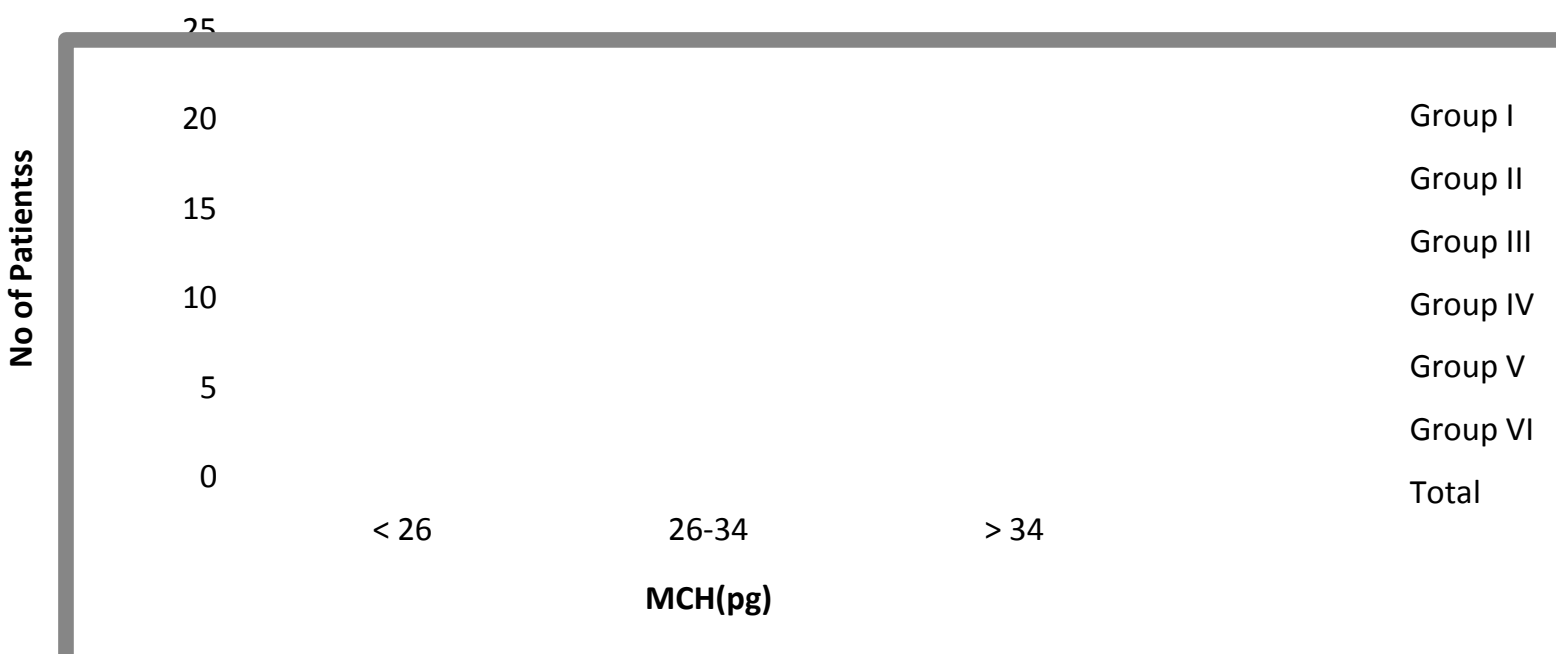


Table - 8: MCHC values in the study groups

\begin{tabular}{|c|c|c|c|c|c|c|c|c|}
\hline \multicolumn{2}{|c|}{ Groups } & $\begin{array}{c}\text { Group } \\
\text { I }\end{array}$ & $\begin{array}{c}\text { Group } \\
\text { II }\end{array}$ & $\begin{array}{c}\text { Group } \\
\text { III }\end{array}$ & $\begin{array}{c}\text { Group } \\
\text { IV }\end{array}$ & $\begin{array}{c}\text { Group } \\
\text { V }\end{array}$ & $\begin{array}{c}\text { Group } \\
\text { VI }\end{array}$ & Total \\
\hline \multirow{2}{*}{$\begin{array}{l}\text { MCHC } \\
\text { (g/dl) }\end{array}$} & $<31$ & $2(50 \%)$ & $3(50 \%)$ & $5(45.45 \%)$ & $2(40 \%)$ & $3(33.33 \%)$ & $5(33.33 \%)$ & $20(40 \%)$ \\
\cline { 2 - 9 } & $>37$ & $2(50 \%)$ & $1(16.67 \%)$ & $2(18.18 \%)$ & - & $1(11.11 \%)$ & $6(40)$ & $12(24 \%)$ \\
\hline
\end{tabular}

\section{Chart 8: MCHC VALUES}

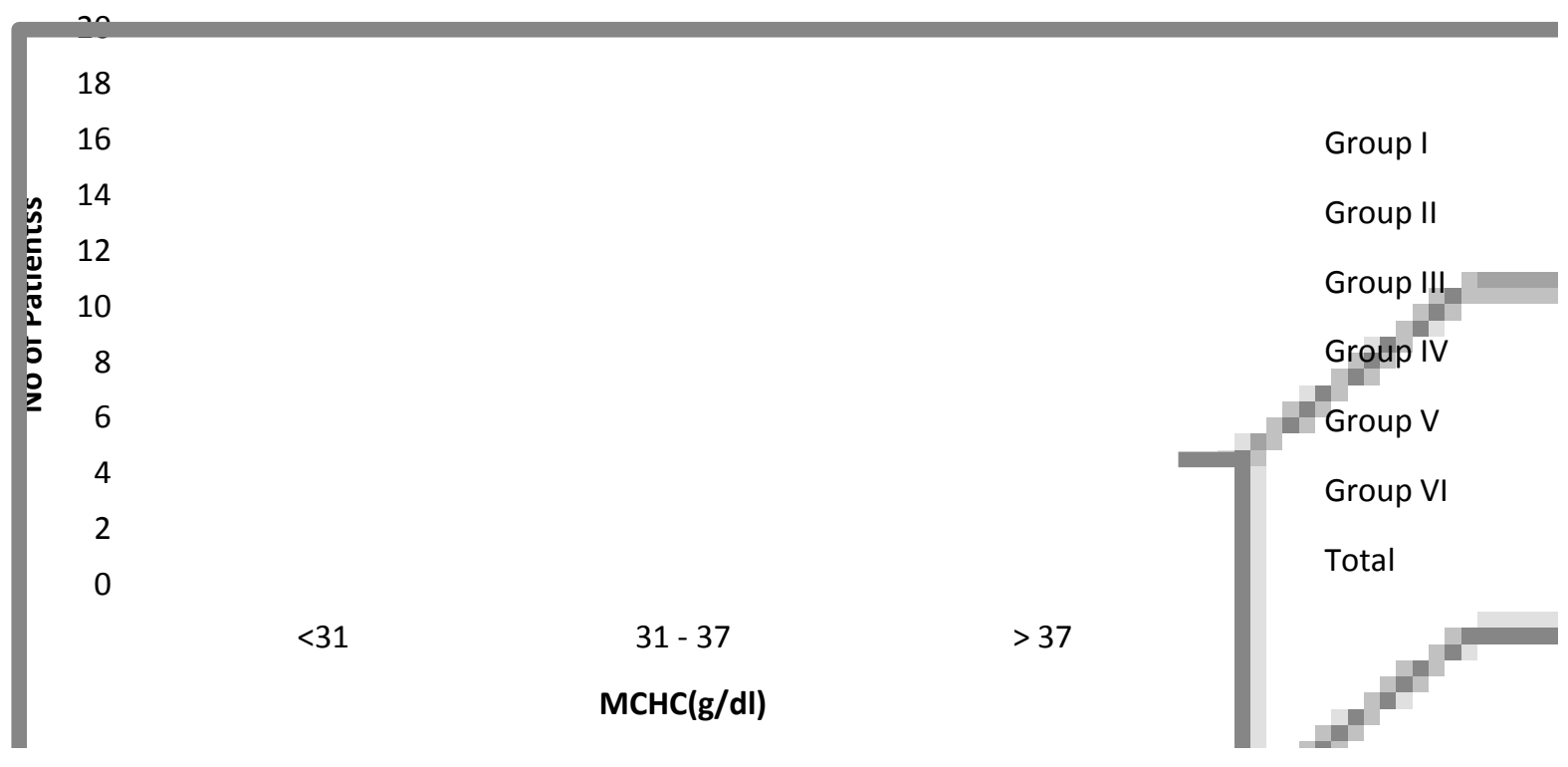

TABLE - 9: RDW values in the study groups

\begin{tabular}{|c|c|c|c|c|c|c|c|c|}
\hline \multicolumn{2}{|c|}{ Groups } & $\begin{array}{c}\text { Group } \\
\text { I }\end{array}$ & $\begin{array}{c}\text { Group } \\
\text { II }\end{array}$ & $\begin{array}{c}\text { Group } \\
\text { III }\end{array}$ & $\begin{array}{c}\text { Group } \\
\text { IV }\end{array}$ & $\begin{array}{c}\text { Group } \\
\text { V }\end{array}$ & $\begin{array}{c}\text { Group } \\
\text { VI }\end{array}$ & Total \\
\hline \multirow{2}{*}{$\begin{array}{c}\text { RDW } \\
(\%)\end{array}$} & $10.0<16.0$ & $2(50 \%)$ & $2(33.33 \%)$ & $4(36.36 \%)$ & $3(60 \%)$ & $5(55.56 \%)$ & $8(53.33 \%)$ & $24(48 \%)$ \\
\cline { 2 - 8 } & $>16.0$ & $2(50 \%)$ & $4(66.67 \%)$ & $7(63.63 \%)$ & $2(40 \%)$ & $4(44.44 \%)$ & $7(46.67 \%)$ & $26(52 \%)$ \\
\hline
\end{tabular}




\section{ORIGINAL REPORT}

\section{Chart 9: RDW VALUES}

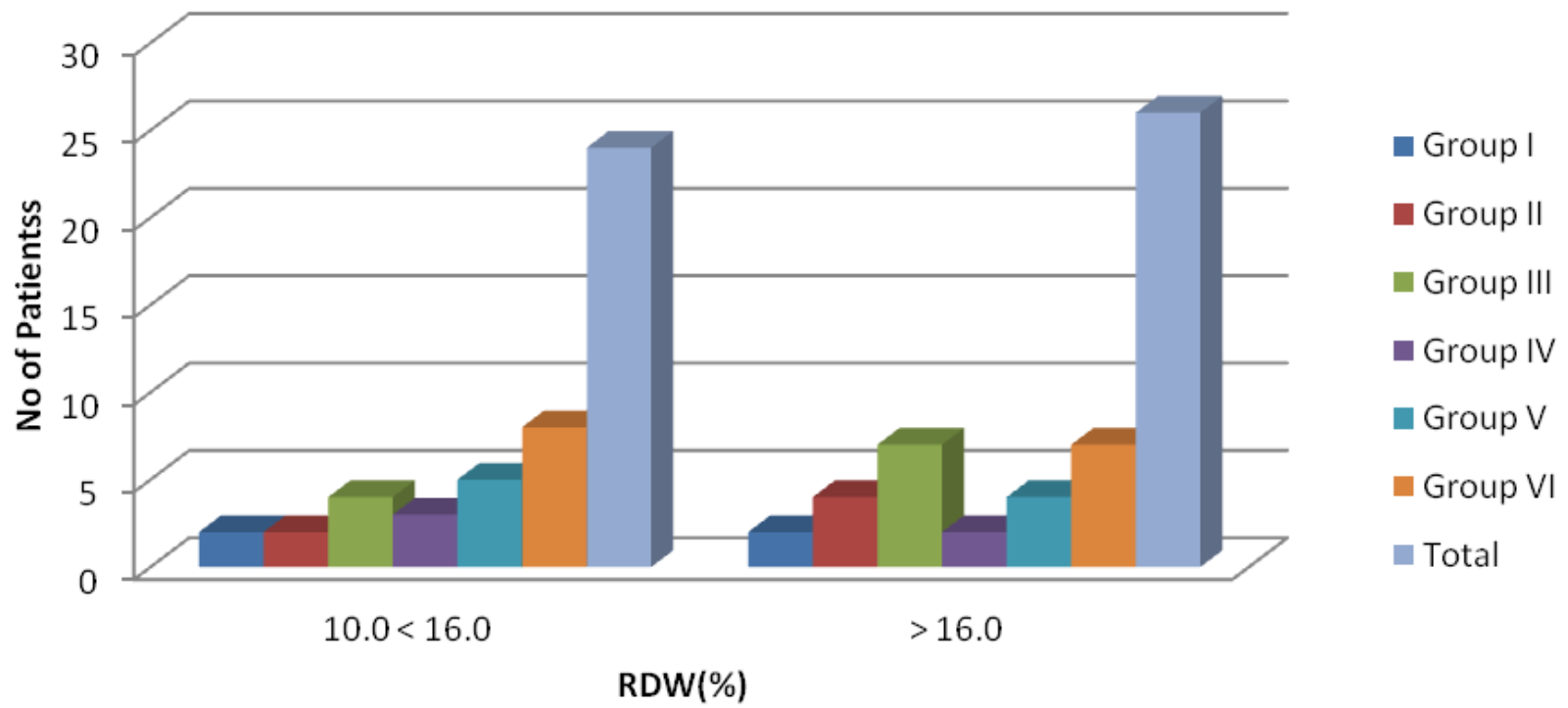

Table - 10: Serum Iron in 18 Patients

\begin{tabular}{|c|c|}
\hline SERUM IRON $(\boldsymbol{\mu g} / \mathbf{d l})$ & PATIENTS \\
\hline$<60.0$ & $12(75 \%)$ \\
\hline $60.0-180.0$ & $6(25.0 \%)$ \\
\hline
\end{tabular}

Chart 10 - a: Serum Iron values in 18 patients

Serum Iron

$<60.0$

$60.0-180.0$ 


\section{ORIGINAL REPORT}

Chart 10 - b: Serum Iron values in 18 patients

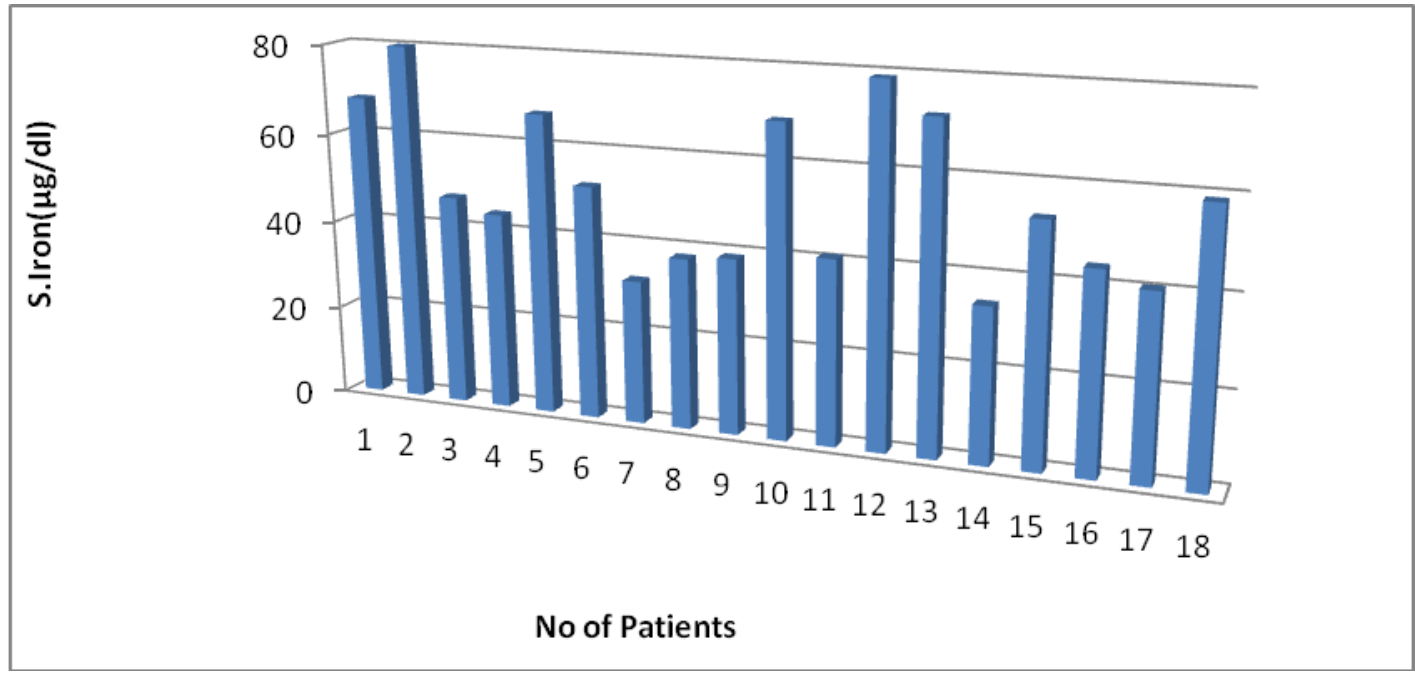

Table - 11: TIBC in 18 patients

\begin{tabular}{|c|c|}
\hline TIBC $(\boldsymbol{\mu g} / \mathbf{d l})$ & PATIENTS \\
\hline$>440.0$ & $12(66.7 \%)$ \\
\hline $240.0-440.0$ & $6(33.3 \%)$ \\
\hline
\end{tabular}

Chart 11 - a: TIBC Iron values in 18 patients

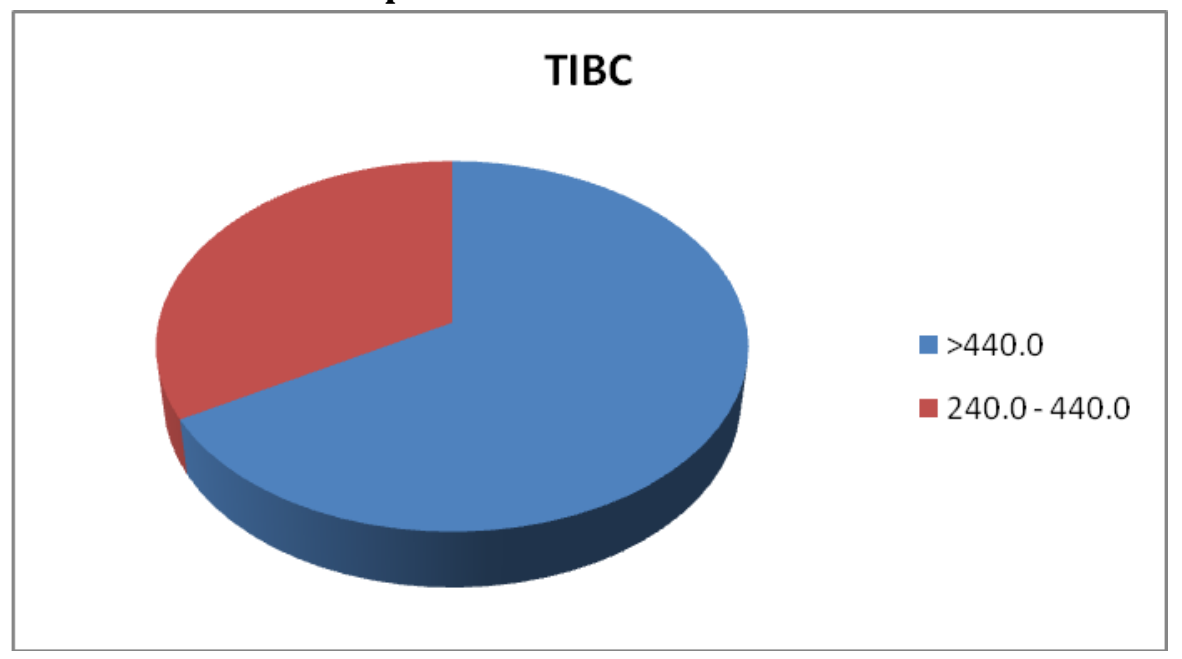




\section{ORIGINAL REPORT}

Chart 11 - b: TIBC iron values in 18 patients

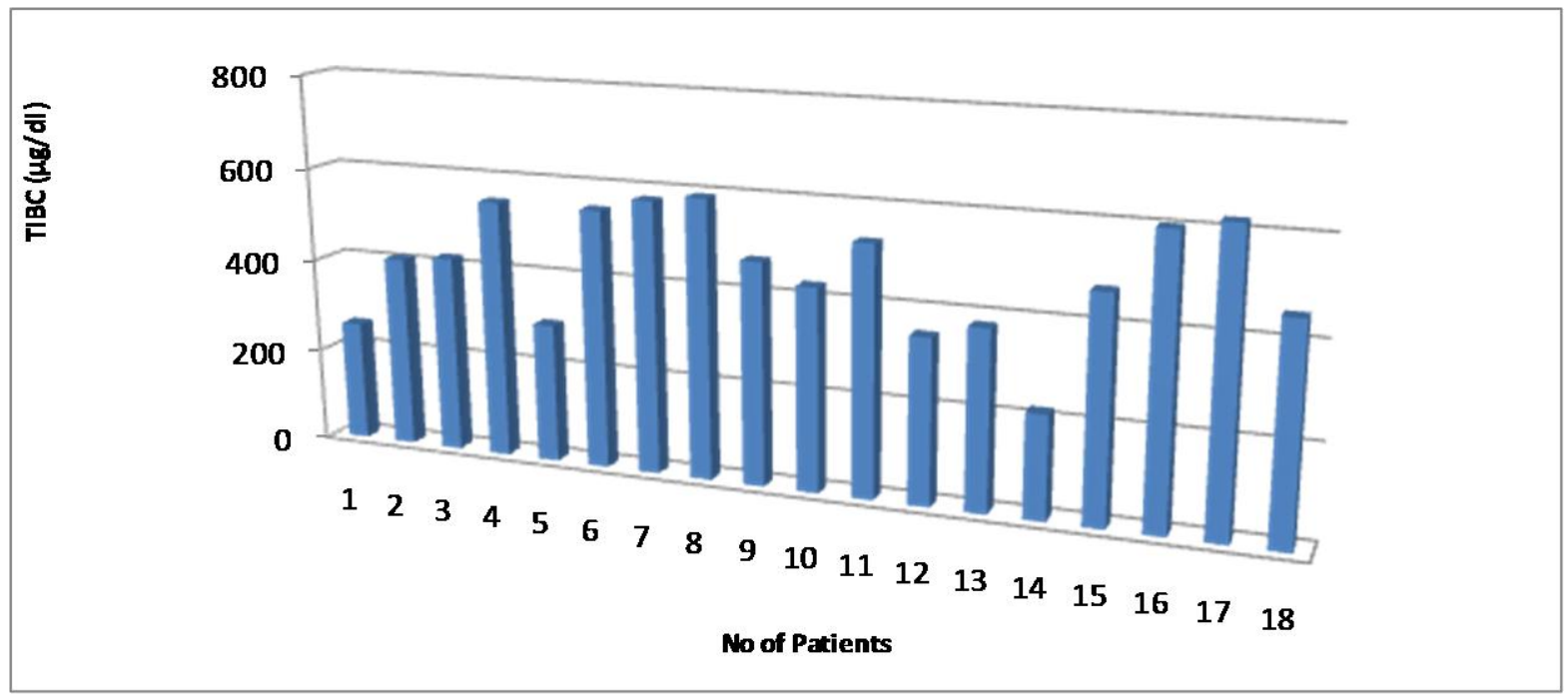

Table - 12: \% Saturation In 18 Patients

\begin{tabular}{|c|l|}
\hline $\begin{array}{c}\text { PERCENT } \\
\text { SATURATION }\end{array}$ & PATIENTS \\
\hline$<30$ & $12(66.7 \%)$ \\
\hline$>30$ & $6(33.3 \%)$ \\
\hline
\end{tabular}

Chart 12 - a: \% Saturation 18 patients

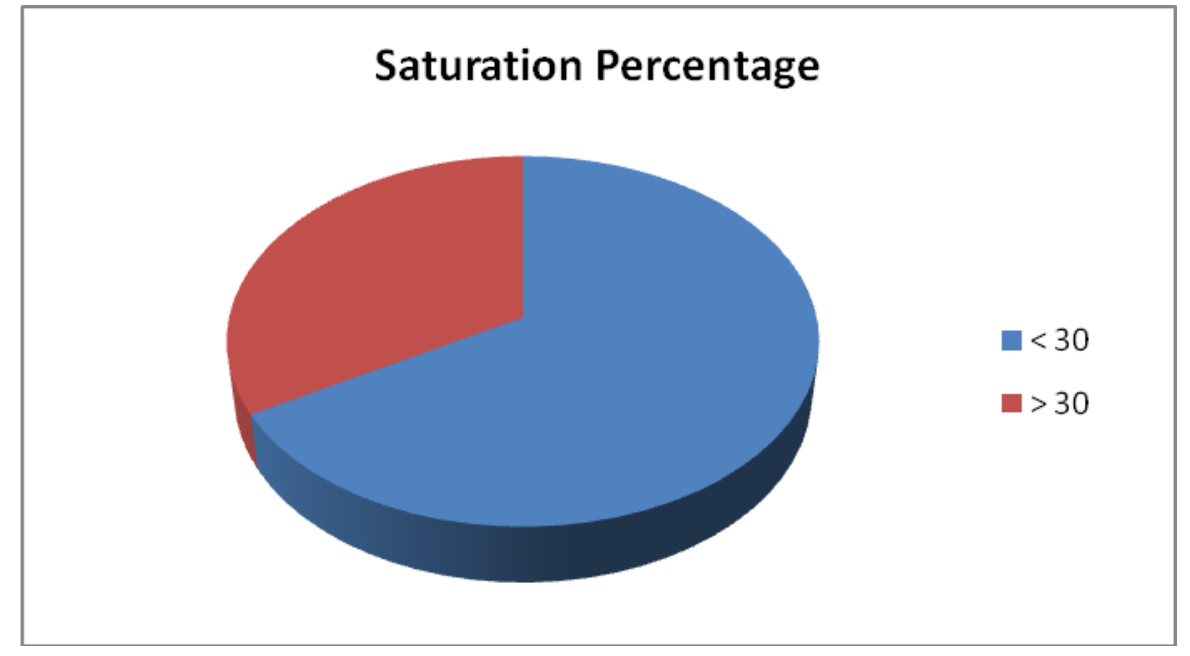




\section{ORIGINAL REPORT}

Chart 12 - b: Percent saturation values in 18 patients

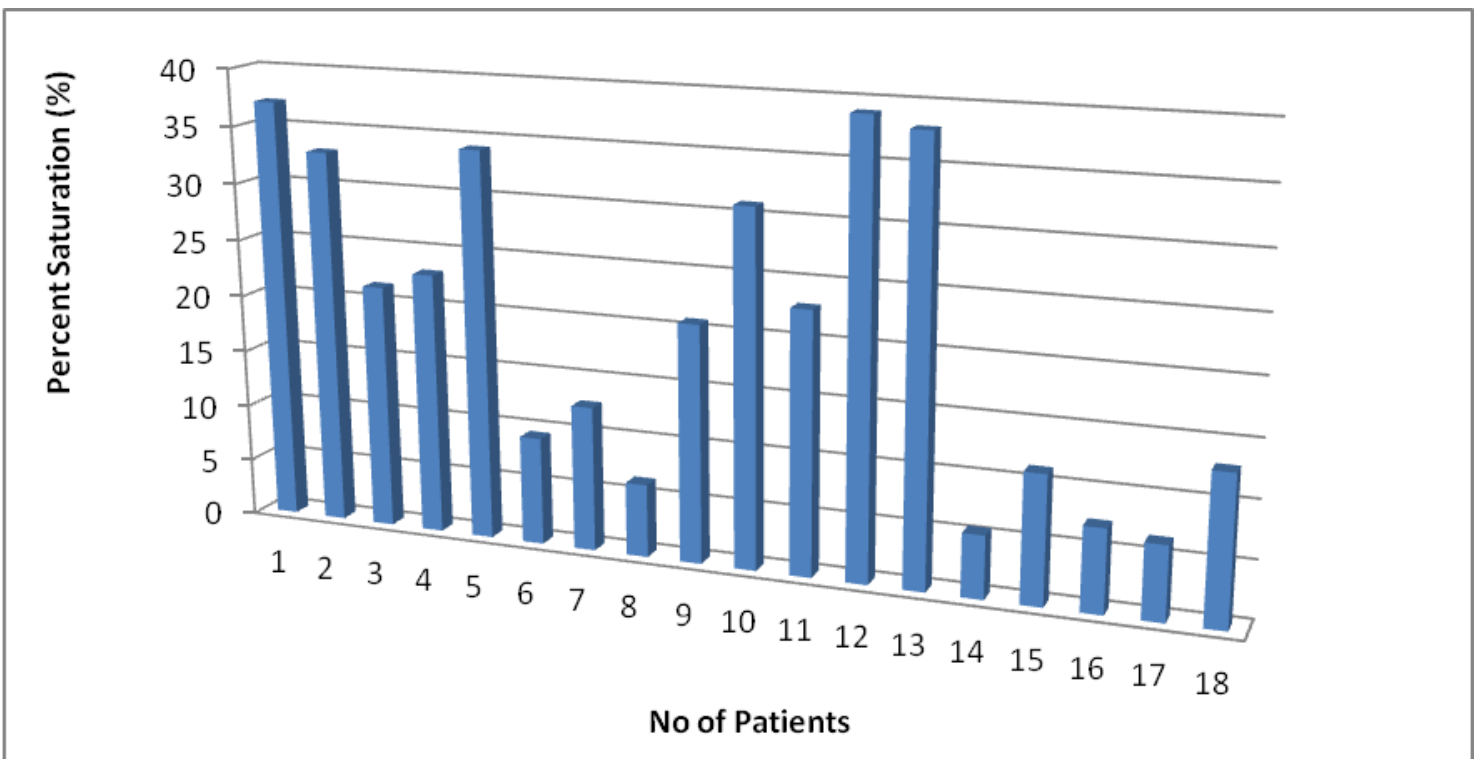

Table - 13: Serum Ferritin in 18 patients

\begin{tabular}{|c|c|}
\hline $\begin{array}{c}\text { SERUM FERRITIN } \\
(\boldsymbol{\mu g} / \mathbf{l})\end{array}$ & PATIENTS \\
\hline$<20.0$ & $12(91.7 \%)$ \\
\hline $20.0-25.0$ & $6(8.3 \%)$ \\
\hline
\end{tabular}

Chart 13 - a: \% Saturation 18 patients

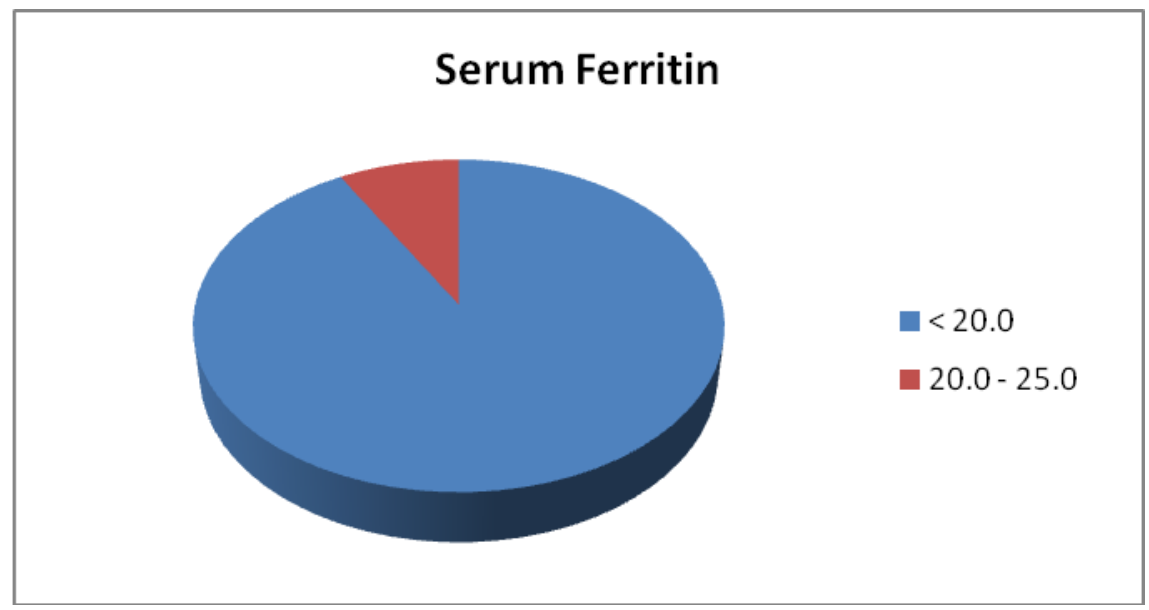




\section{ORIGINAL REPORT}

\section{Chart 13 - b: serum ferritin values in 18 patients}

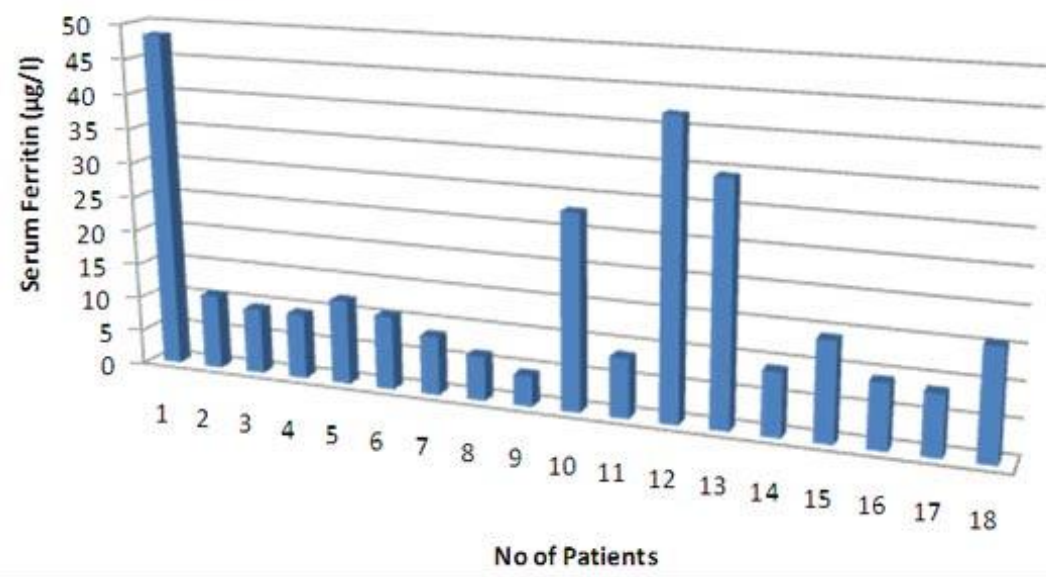

Table 14: Prevalence of Anemia

\begin{tabular}{|c|l|c|}
\hline Sl. No. & \multicolumn{1}{|c|}{ AUTHORS (YEAR) } & PREVALECE (\%) \\
\hline 1. & Malhotra Ak et al $^{61}(1982)$ & 77 \\
\hline 2. & Agarwal DK et al $^{65}(1989)$ & 93 \\
\hline 3. & Verma et al $^{59}(1998)$ & 66.7 \\
\hline 4. & National Family Health Survey-266 $(2000)$ & 69 \\
\hline 5. & Sunil Gomber et al ${ }^{64}(2003)$ & 41.8 \\
\hline 6. & Present Study $(2013)$ & 66 \\
\hline
\end{tabular}

\section{Chart 14: Prevalence of Anemia}

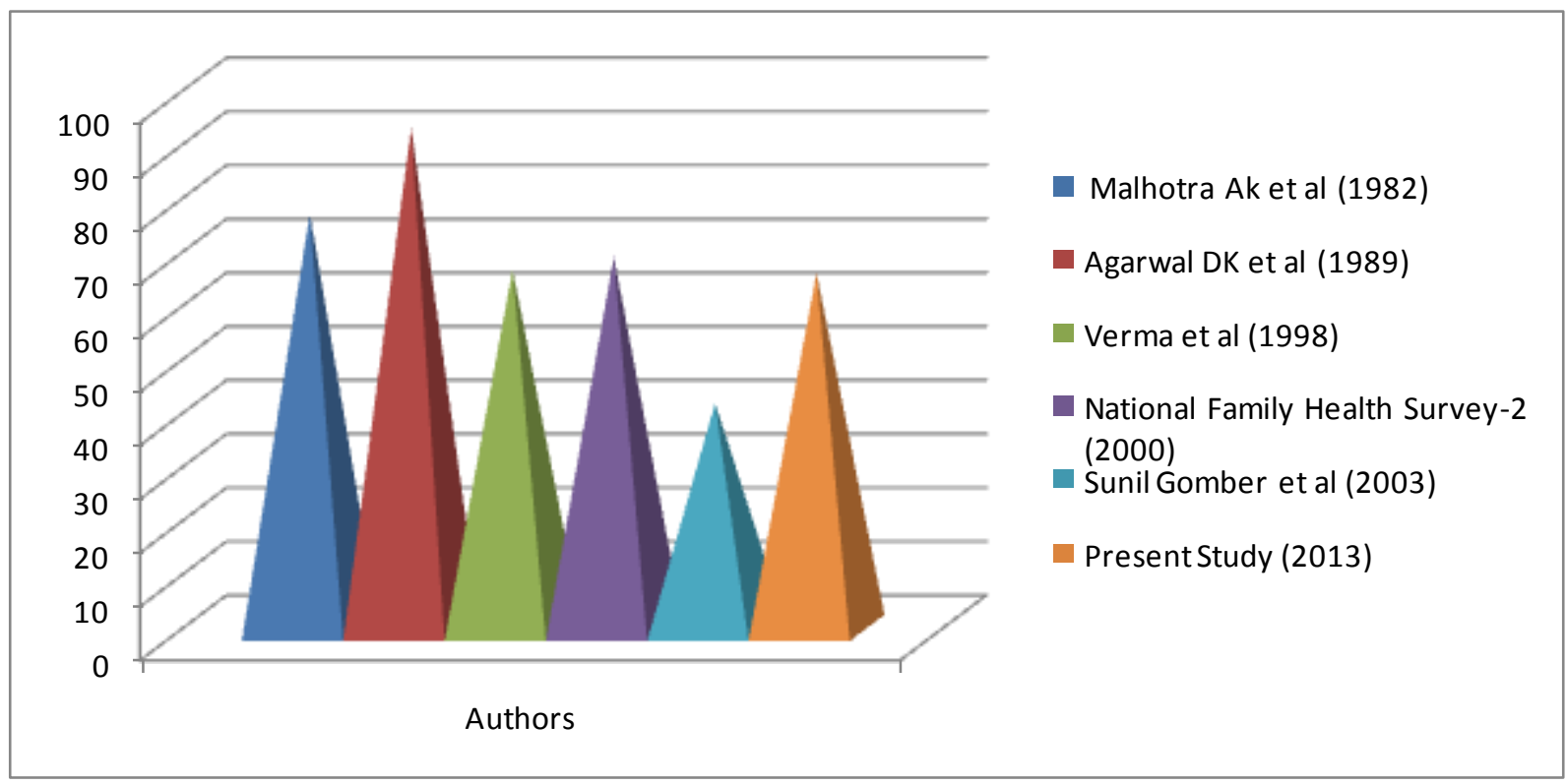


Table 15: Sex distribution of anemia

\begin{tabular}{|c|c|c|c|c|c|}
\hline $\begin{array}{c}\text { Study Group } \\
\text { (year) }\end{array}$ & $\begin{array}{c}\text { Gomber et al } \\
(1998)\end{array}$ & $\begin{array}{c}\text { Kapur et al } \\
(2002)\end{array}$ & $\begin{array}{c}\text { Sunil Gomber et al }{ }^{15} \\
(2003)\end{array}$ & $\begin{array}{c}\text { Halileh et al }^{19} \\
(2005)\end{array}$ & $\begin{array}{c}\text { Present } \\
\text { Study } \\
(2013)\end{array}$ \\
\hline Male: Female & $1.4: 1$ & $1: 1$ & $1.2: 1$ & $1: 1$ & $1: 1.1$ \\
\hline
\end{tabular}

\section{Chart 15: Sex Distribution of Anemia}

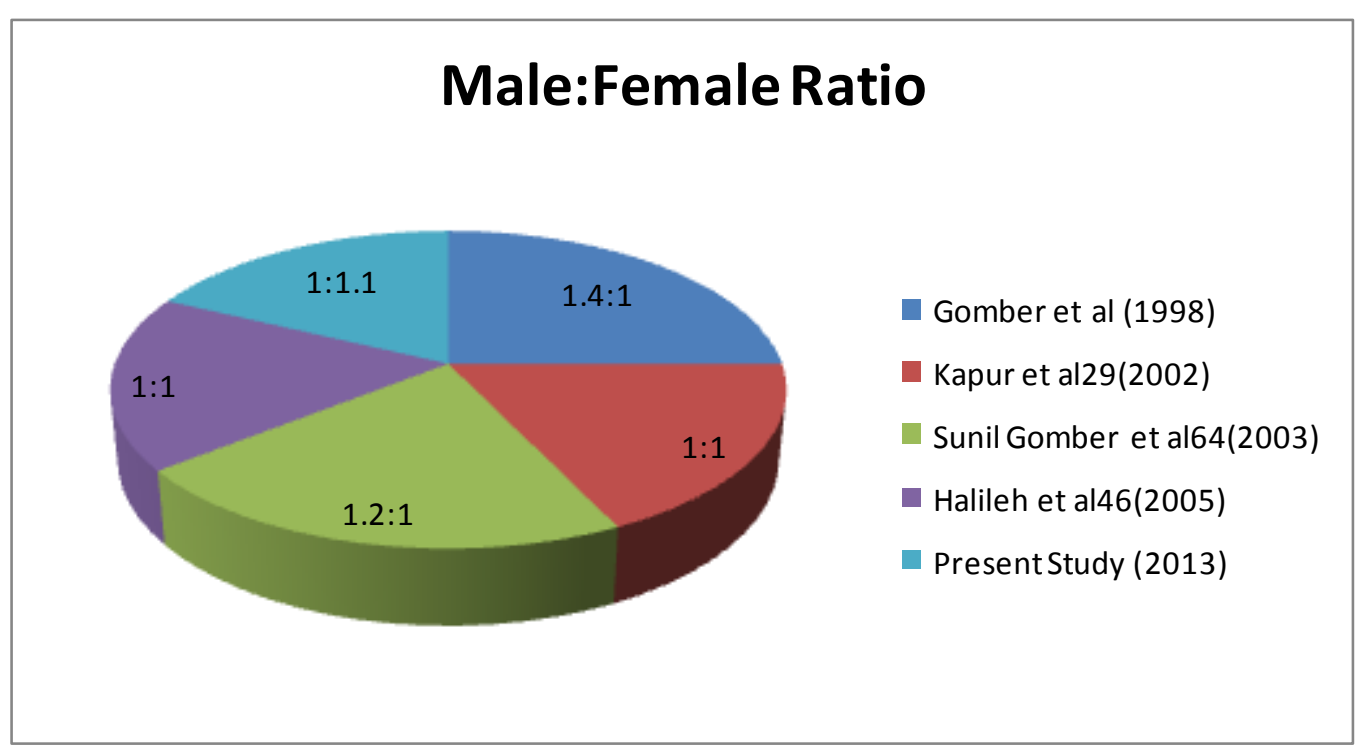

Table 16: Types of Anaemia seen in the study group.

\begin{tabular}{|c|l|c|}
\hline Sl. No. & TYPES OF ANEMIA & NO. OF CHILDREN \\
\hline 1. & Microcytic Hypochromic & 29 \\
\hline 2. & Normocytic Normochromic & 13 \\
\hline 3. & Macrocytic Normochromic & 8 \\
\hline
\end{tabular}




\section{AUTHORS:}

1. Mamina Bhoi

2. B. Krishnaswamy

3. P. Viswanathan

4. L. Lakshmana Rao

\section{PARTICULARS OF CONTRIBUTORS:}

1. IIIrd Year Post Graduate, Department of Pathology, Rajah Muthiah Medical College, Annamalai University.

2. Professor, Department of Pathology, Rajah Muthiah Medical College, Annamalai University.

3. Professor, Department of Pathology, Rajah Muthiah Medical College, Annamalai University.
4. Head of the Department, Department of Pathology, Rajah Muthiah Medical College, Annamalai University.

\section{NAME ADDRESS EMAIL ID OF THE CORRESPONDING AUTHOR:}

Dr. P. Viswanathan, Department of Pathology, Faculty of Medicine,

Rajah Muthiah Medical College, Annamalai University, Chidambaram, Tamilnadu, India, Pin - 608002 .

Email - drpviswanathan2013@gmail.com

Date of Submission: 23/07/2013.

Date of Peer Review: 25/07/2013.

Date of Acceptance: 08/08/2013.

Date of Publishing: 14/08/2013. 